\title{
An Analysis of the Relationship Between Perceived Parental Attitudes and Close Relationship Experiences of Teacher Candidates
}

\section{Öğretmen Adaylarının Algılanan Ebeveyn Tutumları ile Yakın İlişki Yaşantıları Arasındaki İlişkinin İncelenmesi}

\author{
Simel PARLAK* \\ Bahar ŞAHİN-SARKIN**
}

Received: 13 May 2020

Research Article

Accepted: 08 January 2021

ABSTRACT: The study aimed to analyze whether there is a significant relationship between perceived parental attitudes and experiences in close relationships of the individuals in the emerging adulthood period. The study group of this research, which is in the relational screening model, consisted of 272 teacher candidates attending the first, second, third and fourth grades of different departments in the Faculty of Education at a foundation university in Istanbul in the 2018-2019 academic year. Of the students in the study group, 144 (53\%) are female and $128(47 \%)$ are male. The study group who participated in the study was formed by using the appropriate sampling method out of the non-random sampling methods. In the collection of the data of the study, Experiences in Close Relationships Inventory adapted to Turkish by Sümer (2006) and Perceived Parental Attitudes Scale adapted to Turkish by Dirik, Yorulmaz, and Karanc1 (2015) were used. The correlations between the variables studied were calculated by the Pearson Moments Multiplication Correlation coefficient. As a result of the research, a positive and high-level significant relationship was determined between rejecting maternal attitudes and rejecting paternal attitudes regarding perceived paternal attitudes $(r=.736, p<.01)$. Rejecting maternal attitudes showed a positive and low-level significant relationship with the anxiety subscale of the close relationships scale $(r=.181, p<.01)$. Rejecting father attitudes of the perceived parental attitudes showed a positive and low-level significant relationship with the anxiety subscale of the close relationships scale $(r=.174, p<.05)$. The findings obtained were discussed in line with the literature and recommendations were made.

Keywords: Perceived parental attitudes, experiences in close relationships, emerging adulthood.

ÖZ: $\mathrm{Bu}$ araştırmanın amacı, beliren yetişkinlik dönemindeki bireylerin algılanan ebeveyn tutumları ile yakın ilişki yaşantıları arasında anlamlı bir ilişki olup olmadığını incelemektir. İlişkisel tarama modelinde olan bu araştırmanın çalışma grubunu, 2018-2019 eğitim-öğretim yılında İstanbul'da bir vakıf üniversitesinin eğitim fakültesinde farklı bölümlerin birinci, ikinci, üçüncü ve dördüncü sınıfa devam eden toplam 272 öğretmen adayı oluşturmuştur. Çalışma grubunu oluşturan öğrencilerin 1442'ü (\%53) kadın 128'i (\%47) erkektir. Araştırmanın çalışma grubu oluşturulurken seçkisiz olmayan örnekleme yöntemlerinden olan uygun örnekleme yöntemi tercih edilmiştir. Araştırmada veri toplama amacı ile Sümer (2006) tarafından Türkçe'ye uyarlanan Yakın İlişkilerde Yaşantılar Envanteri ve Dirik, Yorulmaz ve Karancı (2015) tarafından Türkçe'ye uyarlanan Algılanan Ebeveyn Tutumları Ölçeği kullanılmıştır. Ele alınan değişkenler arasındaki ilişkiler Pearson Momentler Çarpımı Korelasyon katsayısı ile hesaplanmıştır. Araştırmanın sonucunda, algılanan ebeveyn tutumlarından reddedici anne tutumları, reddedici baba tutumları arasında yüksek düzeyde pozitif yönlü anlamlı bir ilişki $(r=.736, p<.01)$ olduğu belirlenmiştir. Reddedici anne tutumları ile yakın ilişkiler ölçeğinin kaygı alt boyutu arasında pozitif yönlü, düşük düzeyde anlamlı bir ilişki ( $r=.181$, $p<.01)$ olduğu belirlenmiştir. Algılanan ebeveyn tutumlarından reddedici baba tutumları ile yakın ilişkiler ölçeğinin kaygı alt boyutu arasında pozitif yönlü, düşük düzeyde anlamlı bir ilişki $(r=.174, p<.05)$ olduğu belirlenmiştir. Elde edilen bulgular alanyazın doğrultusunda tartışılmış ve önerilerde bulunulmuştur.

Anahtar kelimeler: Algılanan ebeveyn tutumları, yakın ilişkilerde yaşantılar, beliren yetişkinlik.

* Corresponding Author: Asst. Prof. Dr., Okan University, İstanbul, Turkey, simelparlak@gmail.com, https://orcid.org/0000-0002-8651-2693

** Asst. Prof. Dr., Okan University, İstanbul, Turkey, bahar.sarkin@okan.edu.tr, https://orcid.org/0000-0002-11556114

\section{Citation Information}

Parlak, S., \& Şahin-Sarkın, B. (2021). An analysis of the relationship perceived parental attitudes and close relationship experiences of teacher candidates. Kuramsal Eğitimbilim Dergisi [Journal of Theoretical Educational Science], 14(1), 64-78. 
The family environment in which the individual is born, taken care of and raised, the types of interaction in this environment, and attitudes of the parents towards each other and the child define the child's character and life pattern in the future (Perris, 1994). From the perspective of object relations theory, the direct influence of the attitudes of the caregiver on the personality organization of the individual is emphasized. The relationship established with the caregiver in the early periods and internal representations formed by the individual regarding these relationships affect his/her interpersonal relationships, emotions and thoughts at the conscious and unconscious level (Calabrese, Farber, \& Westen, 2005).

One of the pioneers of the object relations theory, Klein explains the child's internal world within the framework of object relations. The first phase at this stage is the paranoid-schizoid position. The child uses a split mechanism in order to purge the good internal objects from the bad ones. The second phase is the depressive position. The object is purged from its excessively good and excessively bad aspects and assumes a more realistic position. However, in this phase, the child experiences a depressive anxiety resulting from the damage caused on the liked object by his/her aggressive and paranoid emotions (Klein, 2008). Kernberg, on the other hand, divides the relationship between the caregiver and the child into phases. In the symbiotic phase, there are primary merged self-object representations. In the next phase, self-representations and object-representations are separated. With the integration of self- and objectrepresentations, the process is completed (Kernberg, 2008). Kohut focuses on "good enough" parenting in the development of the individual. He dwells on the relationship between parenting attitudes and the individual's narcissistic structures. He states that as a result of losing the idealized parental image in the early period in a traumatic way, narcissistic disorders occur in the personality of the individual (Kohut, 1998). In the study conducted by Bedel \& Işık, (2015), they determined students from single-parent families approached more negatively when compared with their counterparts.

Another theory studying the effects of the relationship between the parents and the child on the individual's well-being, personality organization and mental health is Bowlby's (1973, 1980) attachment theory. Emphasizing the search for a close bond, secure base and a monotropic interaction between the infant and the caregiver, Bowlby (1973, 1980) argues that two basic attachment forms develop as a result of the interaction between the parent and the child. While a secure attachment develops as a result of the child being raised by the parent in an uninterrupted, consistent and sensitive relationship, the child develops an insecure attachment in case of an opposite situation, and thereby she/he cannot develop positive internal models related to self and others. While the securely attached child has a loving and caring self-functioning model, the child with an insecure attachment sees himself/herself as inefficient and not worthy of being loved.

When the theories explaining the relationship between the caregiver and the child are examined, it is seen that the interaction between the parents and the child plays an important role in the individual's personality structure and mental health. When perceived parental attitudes are considered from this perspective, the determinacy of emotional warmth, over-protection and rejection factors can be seen. Emotional warmth that defines the physical and verbal expression of the emotion felt by the parent for the child builds a supportive and healthier atmosphere for the child. Over-protective 
behaviors of the parent in the over-protection dimension and anxious attitudes regarding his/her security prevent the child from being autonomous. In the rejection dimension, the parent's critical and judging attitude causes the child to be deprived of the warmth and supportive attitude s/he needs and to be exposed to negligence (Arrindell \& Engebretsen, 2000; Rohner, Khaleque, \& Cournoyer, 2005).

When looking at the studies on the close relationships in terms of emerging adults; It is seen that studies are carried out in many areas such as irrational beliefs, (Çavdar, 2013; Metts, \& Cupach, 1990), relationship satisfaction and investment (Korkmaz, 2020), self-esteem (Duramaz, 2020) ways of dealing with jealousy (Hoşoğlu, 2017), love attıtude styles (Şahin-Sarkın \& Parlak, 2020) attachment styles (Sümer, 2006; Towler \& Stuhlmacher, 2013), attachment styles, conflict resolution strategies and negative moods (Bahadır, 2006), gender, attachment styles, irrational beliefs and attitudes towards love (Beştav, 2007), conflict behavior (Russell-Chapin, Chapin, \& Sattler, 2001), communication styles (Olderbak \& Figueredo, 2009), perfectionism (Stoeber, 2012), intimate partner violence (Parlak, 2018).

University students in the emerging adulthood period experience identity discovery, indecision, focusing on the self, feeling in-between, and analyzing opportunities as necessitated by their life period. Being in the phase of living separately from their parents and gaining their independence, emerging adults (Arnett, 2004) experience separation from their first objects in order to form their identity, and the effect of their perceptions regarding these in this process is observed (Santrock, 2012). Emerging adults, who are in the phase of intimacy versus isolation, are in the process of establishing emotionally intense and long-lasting relationships along with a romantic relationship (Öztürk, 1994; Santrock, 2012). Romantic relationships are a fundamental dynamic that enables the individual to develop relationship skills and establish intimacy in the emerging adulthood period and provide a healthy transition to adulthood. Behavior patterns of the caregiver affect the individual's close relationship style, expectations, beliefs and attitudes throughout his/her life. In this respect, attachment style directly affects the romantic relationship process experienced in adulthood (Bartholomew \& Horowitz, 1991; Hazan \& Shaver, 1987). Problems that can be experienced in romantic relationships bring the risk of affecting the individual's other living areas. The study aimed to examine the relationship between perceived parental attitudes and experiences in close relationships in terms of emerging adults.

\section{Method}

\section{Research Design}

Since the study aimed to determine whether there is a significant relationship between Perceived Parental Attitudes scores and Experiences in Close Relationships scores of teacher candidates, the research was conducted with relational screening model. Relational researches are research patterns aimed at determining whether there is a significant relationship between two or more variables or not (Karasar, 2009). Ethics Committee approval numbered 56665618-204.01.07 was obtained for the research. All procedures performed in studies involving human participants were in accordance with the ethical standards of the institutional and/or national research committee. The purpose and scope of the research was explained to the participants. 


\section{Study Group}

The study group who participated in the study was formed by using the appropriate sampling method out of the non-random sampling methods. Appropriate sampling is mostly preferred when the researcher cannot make use of other sampling methods due to limited conditions such as time and labor (Yıldırım \& Şimşek, 2013). In appropriate sampling, the sample is created beginning from the most accessible answerers until the group with the required size is set (Büyüköztürk, Kılıç-Çakmak, Akgün, Karadeniz, \& Demirel, 2010). In addition, it is thought that it is important to examine the affective feelings of the teacher candidates who will guide the society, especially in the close relationships that will be affected by the future student relations. The study group of the research was composed of a total of 272 teacher candidates, 169 of whom were in Guidance and Psychological Counselling program, 53 were in Preschool Teaching program, 34 were in Special Education Teaching program, and 16 were in English Teaching program, and 65 of the students studying in these programs were first-year students, 36 were second-year students, 89 were third-year students and 82 were fourth-year students in the faculty of education of a foundation university in Istanbul in the 2018-2019 academic year. Of the students in the study group, 144 (53\%) are female and $128(47 \%)$ are male. The mean age of the study group was determined as $21.3(s=3.72)$.

\section{Data Collection Tools}

In the collection of the data of the study, Experiences in Close Relationships Inventory adapted to Turkish by Sümer (2006) and Perceived Parental Attitudes Scale adapted to Turkish by Dirik et al. (2015) were used.

Experiences in close relationships inventory (ECRI). The inventory developed by Brennan, Clark, and Shaver (1998) and adapted to Turkish by Sümer (2006) determines two basic dimensions of attachment, which are anxiety experienced in close relationships and avoidance from individuals. The inventory includes 36 items, and each dimension is measured with 18 items. While the mean score values of add numbered items are taken in order to calculate avoidance score, in order to calculate anxiety score, the mean score values of even numbered items are taken. High scores from the subscale indicate that the level is high in the relevant subscales._The respondents are asked to choose the option in each item that describes themselves on a 7 -point rating scale ranging from $1=$ strongly disagree to $7=$ strongly agree. Items 3,15 , $19,22,25,27,29,31,33$ and 35 are reversely coded. In the factor analysis performed in order to determine construct validity, the factor representing avoidance dimension explained $22 \%$ of the total variance, and the second factor representing anxiety dimension explained $16 \%$ of the total variance. In the adaptation study, a factor structure consistent with the original scale was obtained, and the same factors were gathered under the same factor. Cronbach's alpha coefficient was calculated as .86 for anxiety dimension and as .90 for avoidance dimension, and both dimensions were determined to be highly reliable. In this study, subscales were analyzed for their reliability. Cronbach's alpha coefficient was calculated as .84 for anxiety dimension and as .85 for avoidance dimension. The reliability coefficient of the scale was found to be high for the study group. 
Shortened perceived parental attitude scale - child form (SPPA-C). The scale is the 23-item short form of Egna Minnen Barndoms Uppfostran (EMBU-C) developed by Arrindell and Engebretsen (2000) that determines adults' perceptions of their parents' attitudes towards them in childhood. Validity and reliability study for the Turkish culture was carried out by Dirik et al. (2015). Individuals are asked to respond to each item for their parents on a 4-point Likert type scale (1=never, 2=sometimes, $3=$ often, $4=$ mostly), and only item 17 is reversely coded. The scale is comprised of three subscales, being over-protective attitudes, rejection, and emotional warmth. Over protective parental attitudes, rejecting parental attitudes and emotional warmth parental attitude scores were determined by taking the total scores of perceived parental attitudes towards mothers and fathers in three subscales. The rejection subscale of the scale regarding parental attitudes is composed of 7 items $(1,4,7,13,15,16,21)$, overprotective attitudes subscale includes 9 items $(3,5,8,10,11,17,18,20,22)$ and emotional warmth subscale consists of 7 items $(2,6,9,12,14,19,23)$. Reliability of the scale in terms of internal consistency was determined through Cronbach's alpha coefficient, and it was found to be .79 for father emotional warmth, .73 for father overprotection, .71 for father rejection, .75 for mother emotional warmth, .72 for mother over-protection and .64 for mother rejection. Factor structure of the scale was analyzed in order to determine construct validity, and the relationship between personality characteristics that could be related to psychiatric disorders was examined. In order to determine the scale's criterion validity, two groups were formed according to the scores obtained from Short Symptom Inventory. According to the comparisons between the groups, it was determined that the group which obtained a high score from psychiatric disorder symptoms significantly differed from the other group obtaining a low score from mother-father over-protection and rejection dimensions. In this study, subscales were analyzed for their reliability. Reliability of the scale in terms of internal consistency was determined through Cronbach's alpha coefficient, and it was found to be .75 for father emotional warmth, .72 for father over-protection, .70 for father rejection, .72 for mother emotional warmth, .70 for mother over-protection and .66 for mother rejection.

\section{Data Analysis}

In the research, first of all, descriptive statistics regarding the scores obtained from the scale and inventory applied to the students were calculated. In Tables 1 and 2, variables are coded. They are coded as 1.a:emotional warmth mother, 2.a:emotional warmth father, 1.b:over-protection mother, 2.b:over-protection father, 1.c:rejection mother, 2.c:rejection father, x:avoidance, y:anxiety. Descriptive statistics for the data are presented in Table 1. 
Table 1

Descriptive Statistics for ECRI and SPAA-C Scores

\begin{tabular}{lcccccccc}
\hline & $1 . \mathrm{a}$ & $2 . \mathrm{a}$ & $1 . \mathrm{b}$ & $2 . \mathrm{b}$ & $1 . \mathrm{c}$ & $2 . \mathrm{c}$ & $\mathrm{x}$ & $\mathrm{y}$ \\
\hline $\mathrm{N}$ & 272 & 272 & 272 & 272 & 272 & 272 & 272 & 272 \\
Mean & 21.88 & 20.68 & 20.24 & 19.50 & 9.14 & 9.21 & 3.28 & 3.69 \\
Median & 22.50 & 22.00 & 20.00 & 19.00 & 8.25 & 8.00 & 3.27 & 3.69 \\
Top Value & 22.35 & 21.00 & 20.18 & 19.48 & 8.12 & 8.78 & 3.41 & 3.84 \\
Standard Deviation & 3.77 & 4.46 & 4.86 & 4.98 & 2.62 & 2.88 & 1.10 & 1.20 \\
Variance & 14.24 & 19.92 & 23.62 & 24.87 & 6.87 & 8.29 & 1.19 & 1.43 \\
Skewness Coefficient & -.71 & -.64 & .39 & .55 & .72 & .54 & .05 & .06 \\
Kurtosis Coefficient & .05 & -.03 & -.27 & .11 & .92 & .81 & -.72 & -.36 \\
Kolmogorov-Smirnov & .12 & .14 & .09 & .10 & .21 & .22 & .27 & .25 \\
Kolmogorov-Smirnov $(p)$ & .80 & .70 & .80 & .90 & .70 & .87 & .85 & .82 \\
\hline
\end{tabular}

When Table 1 was examined, it was seen that in the descriptive statistics regarding SPAA-C and ECRI, mean, median and mod values were close to each other. In symmetric distribution, the skewness and kurtosis coefficient values being in the range of \pm 1 is interpreted as proof that the distribution does not show an excessive deviation from the symmetry axis (Çokluk, Şekercioğlu, \& Büyüköztürk, 2010). Skewness and kurtosis coefficients of the scores obtained from the scales can be said to be in the range of \pm 1 . According to these findings, it can be said that the distribution of the scores is close to symmetric distribution. Büyüköztürk (2012) has stated that Kolmogorov-Smirnov test is a preferred normality test in cases where more than 50 data are present. $\mathrm{P}$ significance value calculated for Kolmogorov-Smirnov test being higher than $\alpha=.05$ indicates that the scores do not significantly deviate from symmetric distribution at this significance level. As can be seen in the findings in Table 1, it was determined that the variables showed a normal distribution. The correlations between the variables studied were calculated by the Pearson Moments Multiplication Correlation coefficient. This coefficient is used to determine the linear relationship between two continuous variables at an at least equal interval scale level (Büyüköztürk, Çokluk, \& Köklü, 2010). A correlation coefficient of .70 and above is interpreted as a strong relationship between the two variables, between $.70-.30$ as a moderate relationship, and below .30 as a weak relationship (Roscoe, 1975). The correlation coefficients calculated in the study were interpreted according to this definition. 


\section{Results}

The findings obtained from the examination of the relationship between perceived parental attitudes and experiences in close relationships from the perspective of emerging adults are presented in Table 2.

Table 2

The Relationships Between ECRI And SPAA-C Scores.

\begin{tabular}{ccccccccc}
\hline Variable & $1 . \mathrm{a}$ & $2 . \mathrm{a}$ & $1 . \mathrm{b}$ & $2 . \mathrm{b}$ & $1 . \mathrm{c}$ & $2 . \mathrm{c}$ & $\mathrm{x}$ & $\mathrm{y}$ \\
\hline $1 . \mathrm{a}$ & 1 & & & & & & \\
$2 . \mathrm{a}$ & $.686^{* *}$ & 1 & & & & & \\
$1 . \mathrm{b}$ & $-.125^{*}$ & -.108 & 1 & & & & & \\
$2 . \mathrm{b}$ & $-.161^{* *}$ & $-.121^{*}$ & $-.745^{* *}$ & 1 & & & & \\
$1 . \mathrm{c}$ & $-.448^{* *}$ & $-.339^{* *}$ & $-.417^{* *}$ & $.367 * *$ & 1 & & & \\
$2 . \mathrm{c}$ & $-.339^{* *}$ & $-.493^{* *}$ & $-.362^{* *}$ & $-.360^{* *}$ & $.736^{* *}$ & 1 & & \\
$\mathrm{x}$ & $-.195^{* *}$ & $-.138^{*}$ & -.027 & .031 & .096 & .092 & 1 & \\
$\mathrm{y}$ & $-.131^{*}$ & $-.135^{*}$ & $.262^{* *}$ & $.289^{* *}$ & $.181^{* *}$ & $.174^{*}$ & $.168^{* *}$ & 1 \\
\hline \multicolumn{2}{c}{$* * p<.01, * p<.05$} & & & & & & &
\end{tabular}

When Table 2 is examined, it is seen that there was a positive, strong and significant relationship between mother emotional warmth attitudes and father emotional warmth attitudes $(r=.686, p<.01)$ among perceived parental attitudes. Mother emotional warmth attitudes showed a negative and weakly significant relationship between mother over-protection attitudes and father over-protective attitudes $(r=-.125$, $p<.01 ; r=-.161, p<.01)$, respectively. Mother emotional warmth attitudes showed a negative and middle-level significant relationship with mother and father rejection attitudes $(r=-.448, p<.01 ; r=-.339, p<.01)$. Mother emotional warmth attitudes showed a negative and weakly significant relationship with the avoidance and anxiety subscale of close relationships scale ( $r=-.195, p<.01 ; r=-.131, p<.05)$.

Father emotional warmth attitudes from perceived parental attitudes showed a negative and weakly significant relationship with father over-protection attitudes $(r=-.121, p<.01)$. Father emotional warmth attitudes showed a negative and middle-level significant relationship with mother and father rejection attitudes $(r=-.339, p<.01$; $r=-.493, p<.01$ ), respectively. Father emotional warmth attitudes showed a negative and weakly significant relationship with the avoidance and anxiety subscale of close relationships scale $(r=-.138, p<.01 ; r=-.135, p<.01)$, respectively.

Mother over-protection attitudes from perceived parental attitudes showed a negative and strongly significant relationship with father over-protection attitudes $(r=-.745, p<.01)$. Mother over-protection attitudes showed a negative and middle-level significant relationship with mother and father rejection attitudes ( $r=-.417, p<.01$; $r=-.362, p<.01)$, respectively. Mother over-protection attitudes showed a positive and weakly significant relationship with the anxiety subscale of close relationships scale 
$(r=.262, p<.01)$. Mother over-protection attitudes didn't show a significant relationship with the avoidance subscale of close relationships scale ( $p>.01)$.

While father over-protection attitudes from perceived parental attitudes showed a positive and moderately significant relationship with mother rejection attitudes $(r=.367, p<.01)$, they showed a negative and weakly significant relationship with father rejection attitudes $(r=-.360, p<.01)$. Father over-protection attitudes showed a positive and weakly significant relationship with the anxiety subscale of close relationships scale $(r=.289, p<.01)$. Father over-protection attitudes didn't show a significant relationship with the avoidance subscale of close relationships scale ( $p>.01)$.

Mother rejection attitudes from perceived parental attitudes showed a positive and strongly significant relationship with father rejection attitudes $(r=.736, p<.01)$. Mother rejection attitudes showed a positive and weakly significant relationship with the anxiety subscale of close relationships scale $(r=.181, p<.01)$. Mother rejection attitudes didn't show a significant relationship with the avoidance subscale of close relationships scale $(p>.01)$.

Father rejection attitudes from perceived parental attitudes showed a positive and weakly significant relationship with the anxiety subscale of the close relationships scale $(r=.174, p<.05)$. Father rejection attitudes from perceived parental attitudes didn't show a significant relationship with the avoidance subscale of the close relationships scale $(p>.01)$.

\section{Discussion and Conclusion}

The study aimed to examine whether there was a relationship between perceived parental attitudes and experiences in close relationships from the perspective of university students. When Table 2 is examined, it is seen that mother emotional warmth attitudes from perceived parental attitudes showed a positive and strongly significant relationship with father emotional warmth attitudes. In the study conducted by Gittleman, Klein, Smider, and Essex (1998), it was revealed that individuals who had a sufficiently close and warm relationship with their parents displayed a similar pattern in their romantic relationships. In the study conducted by Oktay (2016), it is determined that individuals raised by caregivers with inclusive and emotionally warm attitudes did not display avoidance behavior in their romantic relationships. In the present study, it was seen that the parents' attitudes towards their children were influenced by each other and that this influence was effective in positive attitudes. In other words, as the mother's emotional warmth attitudes increase, so do the father's emotional warmth attitudes. Mother-father attitudes support each other in terms of emotional warmth attitudes.

Mother emotional warmth attitudes show a negative and weakly significant relationship with mother and father over-protection attitudes. Similarly, father emotional warmth attitudes from perceived parental attitudes show a negative and weakly significant relationship with father over-protection attitudes. In a similar way, in the study conducted by Çamurlu-Keser (2006), it was determined that as the acceptance and interest of parents increased, there was a decrease in strict control attitude. In the present study conducted, it is seen that as mother emotional warmth attitudes increased, mother-father over-protection attitudes decreased and that in the same way, as father emotional warmth attitudes increased, father over-protection attitudes decreased. 
In the study, mother emotional warmth attitudes and father emotional warmth attitudes, showed a negative and middle-level significant relationship with mother and father rejection attitudes. In the study they conducted, Wearden, Peters, Berry, Barrowclough, and Liversidge (2008) concluded that as the acceptance, interest and warm attitudes of caregivers increased, the individual developed a positive attitude towards the self and the others. In the present study conducted, consistently with the literature, it was found that as mother emotional warmth attitudes and father emotional attitudes increased, mother and father rejection attitudes decreased.

In the traditional social gender roles, while the male's role is to meet the family's economic needs, the female's role is to raise children, feed and maintain order in family life (Gizem \& Keser, 2020). As a result of the study, it was seen that the projection of social gender roles was evident again in that mother over-protection attitudes from perceived parental attitudes showed a negative and strongly significant relationship with father over-protection attitudes. In other words, as the mother overprotection attitude comes into play with the perception of the mother being responsible for the child, the father over-protection attitude is reduced.

Mother over-protection attitudes show a positive and middle-level significant relationship with mother and father rejection attitudes. Besides, father over-protection attitudes show a negative and middle-level significant relationship with father rejection attitudes. Over-protective parent prevents the child from establishing his/her autonomous space and takes over the responsibility for the child's needs and problems without giving him/her a chance to solve them (Bozdemir, 2015). In the study conducted on university students by Demirsu (2018), it was concluded that as emotional warmth increased, the level of anxiety was diminished, and that mother-father rejection attitudes increased anxiety level. In the present study conducted, it was concluded that as mother over-protection attitudes increased, mother-father rejection attitudes decreased, and that as father emotional over-protection attitudes increased, father rejection attitudes decreased. Rohner (1975) stated that over-protective parenting would prevent the child's skills to overcome problems from developing. In their study, Clarke, Cooper, and Creswell (2013) reported that an over-protective parenting style would cause the child to perceive the world as a dangerous and insecure place and thereby hindering his/her development. A low level of rejection attitude as a result of intense interest and control of over-protecting parent is an expected outcome. However, another important point is that an increase in maternal over-protection decreases paternal rejection. This result can be thought to have resulted from the stereotype gender roles stipulating that the mother is responsible for raising the child.

Father over-protection attitudes from perceived parental attitudes showed a positive and moderately significant relationship with mother rejection attitudes. It can be thought that the reason why mother rejection attitudes increased as father overprotection attitudes increased can be that mother is responsible for the child according to traditional social gender roles and that it is often the father who makes the final decision about mother's leaving her role to the father (Amer, 2013). It is believed that the mother's leaving the role regarding raising the child to the father as the final decision maker could prepare the ground for the formation of rejecting perception related to the mother. In the study conducted by Parlak (2018), participants held the 
opinion that it must be the father who should have the final say in the home and that it was as how it should be.

Mother rejection attitudes from perceived parental attitudes showed a positive and strongly significant relationship with father rejection attitudes. In the study conducted by Main, Kaplan, and Cassidy (1985), they determined that individuals who had a rejecting relationship with their parents had an insecure attachment style. Rohner (1975) emphasized that rejection attitude of the caregiver leads to a decrease in the individual's self-esteem and emotional instability. As a result of the present study conducted, the fact that as mother rejection attitudes increased, father rejection attitudes increased could be indicative of many dynamics such as a conflict between the couples etc.

In the study, mother emotional warmth attitudes and father emotional warmth attitudes showed a negative and weakly significant relationship with avoidance and anxiety sub-scales of close relationships scale. Another result of the study was that mother rejection attitudes and father rejection attitudes showed a positive and weakly significant relationship with anxiety sub-scale of close relationships scale. In avoiding attachment, the child who minimizes his needs takes precautions against rejection by the caregiver. By staying at a certain distance, the child minimizes his expectations against the possibility of rejection of the caregiver and remains on the emotional border (Bowlby, 1973, 1980). Rohner (1975) stated that the individual's being accepted or rejected by his/her parents during childhood could directly affect his/her cognitive, emotional and social development. According to Bowlby (1973, 1980), the attachment developing in the first year of an individual's life and the dissociation process of this attachment plays an important role in the individual's positioning himself/herself as a subject. The caregiver's being sufficiently good and inclusive is important for this positioning. These behavior patterns of the caregiver affect the individual's close relationship style, expectations, beliefs and attitudes throughout his/her life. While a child securely attached has a loving and caring self-functioning model, a child insecurely attached sees himself/herself inefficient and unworthy of being loved. Rohner (1986) stated that individuals, who think that their caregivers have rejected them, become anxious and feel insecure. Similarly, in the study conducted by Uyanik, Kaya, İnal-Kızıltepe \& Can-Yaşar (2016), it was found that participants accepted by their parents had secure attachment styles.

The results of the research support this finding. As the mother emotional warmth attitudes and father emotional attitudes increase, avoidance and anxiety decrease. As mother rejection attitudes and father rejection attitudes increase, so does anxiety. In other words, a sufficiently inclusive caregiver ensures the infant's secure attachment throughout adulthood and decreases anxiety and avoidance, which are the components of insecure attachment. According to Yavuzer (1994), children who are raised with an over-protective attitude, lack entrepreneurship and self-confidence, are shy, passive in social relations and develop slowly in terms of certain skills compared to their peers. The overprotective attitude of the parent makes the child think that the world is an unsafe place. Therefore, the child who perceives the world as insecure develops anxious or avoidant attachment. Contrary to the literature, the relationship between overprotective parental attitudes and avoidance-anxiety did not yield a significant result. 
Mother over-protection attitudes showed a positive and weakly significant relationship with anxiety sub-scale of close relationships scale. To Bowlby (1973, 1980), attachment is a primary motivational system and it is in interaction with other systems in its own functioning. Search for closeness, secure base and separation protest with the caregiver in attachment relationship are determinant factors. As a result of the research, it was seen that as mother over-protection attitudes increase, anxiety increases, that an over-protective mother does not provide the child with a secure base, and that therefore, anxiety level also increased in adulthood. Similar to the results of the study conducted, other research also shows that the relationship of the caregiver with the child directly affects attachment style (Çiftçi, 2010; Katalan, 2014; Khaleque \& Rohner, 2002; Salahur, 2010).

Hazan and Shaver (1987) revealed the effects of the parent-child relationship on the child's mental structure and attachment style and concluded that the attachment pattern in childhood directly affects the attachment style experienced in romantic relationships. From this perspective, the caregiver's being sufficiently inclusive and showing an emotional warmth attitude determines the child's future and relationships. All these findings considered, it is believed that planning of psycho-educational programs regarding parenting and attachment process will be an important step for the future generations to become healthy individuals and establish healthy families. It is thought that these programs can be intended for parents-to-be or can be added to the curriculum of university students. The relationship between close relationship and parental attitude which is considered in the research with quantitative dimension can be supported by qualitative studies. Also, the development of attachment patterns can be observed with longitudinal studies.

\section{Statement of Responsibility}

Simel Parlak; conceptualization, methodology, validation, formal analysis, investigation, resources, data curation, writing - original draft, writing - review \& editing, visualization, supervision, project administration. Bahar Şahin-Sarkın; conceptualization, methodology, validation, writing - original draft, writing - review \& editing, visualization, supervision, project administration. 


\section{References}

Amer, M. (2013). Combining academic career and motherhood: experiences and challenges of women in academia. International Research Journal of Social Sciences, 2(4), 12-15.

Arnett, J. J. (2004). Emerging adulthood. New Jersey: Prentice-Hall.

Arrindell, W. A., \& Engebretsen, A. A. (2000). Convergent validity of the short-EMBU1 and the parental bonding instrument (PBI): Dutch findings. Clinical Psychology \& Psychotherapy: An International Journal of Theory \& Practice, 7(4), 262-266.

Bahadır, Ş. (2006). Romantik ilişkileri bağlanma stilleri, çatışma çözme startejileri ve olumsuz duygu durumunu düzenleme arasındaki ilişki (Yayımlanmamış doktora tezi). Ankara Üniversitesi, Ankara.

Bartholomew, K., \& Horowitz, L. M. (1991). Attachment styles among young adults: A test of a four-category model. Journal of Personality and Social Psychology, 61(2), 226-244.

Bedel, A., \& Işık, E. (2015). A comparison of interpersonal problem solving and life satisfaction level between students with single parents and two parents. Journal of Theoretical Educational Science, 8(1), 70-85. Retrieved from https://dergipark.org.tr/tr/pub/akukeg/issue/29356/314121

Beştav, G. F. (2007). Romantik ilişki doyumu ile cinsiyet, bağlanma stilleri, rasyonel olmayan inançlar ve aşka ilişkin tutumlar arasındaki ilişkilerin incelenmesi (Yayımlanmamış yüksek lisans tezi). Hacettepe Üniversitesi, Ankara.

Bowlby, J. (1973). Attachment and loss: Separation, anxiety and anger. New York: Basic Books.

Bowlby, J. (1980). Attachment and loss. New York: Basic Books.

Bozdemir, F. (2015). Bağlanma stilleri, anne baba tutumları ve çocukluk çă̆ örselenme yaşantılarının duygusal zekâ ile ilişkilerinin incelenmesi (Yayımlanmamış yüksek lisans tezi). Mersin Üniversitesi, Mersin.

Büyüköztürk, Ş. (2012). Sosyal bilimler için veri analizi el kitabı (12. bask1). Ankara: Pegem Akademi Yayıncılık.

Büyüköztürk, Ş., Kılıç-Çakmak, E., Akgün, Ö. E., Karadeniz, Ş., \& Demirel, F. (2010). Bilimsel araştırma yöntemleri (7. baskı). Ankara: Pegem Akademi Yayıncılık.

Büyüköztürk, Ş., Çokluk, Ö., \& Köklü, N. (2010). Sosyal bilimler için istatistik (5. bask1). Ankara: Pegem Akademi Yayıncılık.

Calabrese, L. M., Farber, A. B., \& Westen, D. (2005). The relationship of adult attachment constructs to object relational patterns of representing self and others. Journal of The American Academy of Psychoanalysis and Dynamic Psychiatry, 33(3), 513-530. http://dx.doi.org/10.1521/jaap.2005.33.3.513

Clarke, K., Cooper, P., \& Creswell, C. (2013). The parental over protection scale: Associations with child and parental anxiety. Journal of Affective Disorders, 151(2), 618-624. http://dx.doi.org/10.1016/j.jad.2013.07.007

Çamurlu-Keser, C. (2006). Annenin bağlanma düzeyi ve çocuk yetiştirme sürecinin çocuğun bağlanma düzeyine etkisi (Yayımlanmamış yüksek lisans tezi). Uludağ Üniversitesi, Bursa. 
Çavdar, D. (2013). Üniversite öğrencilerinin toplumsal cinsiyet rollerine ilişkin tutumları ve romantik ilişkilerde akılcı olmayan inançları (Yayımlanmamış yüksek lisans tezi). Ankara Üniversitesi, Ankara.

Çiftçi, D. (2010). Kişinin ebeveyn ilişki algısı ile yetişkinlik bağlanma stilleri arasındaki ilişkinin incelenmesi (Yayımlanmamış yüksek lisans tezi). Maltepe Üniversitesi, İstanbul.

Çokluk, Ö. S., Şekercioğlu, G., \& Büyüköztürk, S. (2010). Sosyal bilimler için çok değişkenli istatistik: spss ve lisrel uygulamaları. Ankara: Pegem Akademi Yayıncilik.

Demirsu, Ö. (2018). Üniversite ögrrencilerinde algllanan ebeveyn tutumlart ile sürekli kaygı düzeyleri arasındaki ilişkide psikolojik dayanıklılığın ve kayg duyarlılı̆̆ının aracı rolleri (Yayımlanmamış yüksek lisans tezi). Işık Üniversitesi, İstanbul.

Dirik, G., Yorulmaz, O., \& Karancı, N. (2015). Çocukluk dönemi ebeveyn tutumlarının değerlendirilmesi: Kısaltılmış algılanan ebeveyn tutumları-Çocuk formu. Türk Psikiyatri Dergisi, 26(2), 123-130. Retrieved from http://www.turkpsikiyatri.com/PDF/C26S2/06.pdf on 12.03.2018.

Duramaz, A. (2020). Evli bireylerde romantik ilişkilerde akllcı olmayan inançlar ile evlilik doyumu ve benlik saygısı arasındaki ilişkide romantik yakınlığın aracı rolünün incelenmesi (Yayımlanmamış yüksek lisans tezi). Mersin Üniversitesi, Mersin.

Gittleman, M. G., Klein, M. H., Smider, N. A., \& Essex, M. J. (1998). Recollections of parental behaviour, adult attachment and mental health: mediating and moderating $\begin{array}{llll}\text { effects. } & \text { Psychological } & \text { 1443-1455. }\end{array}$ http://dx.doi.org/10.1017/S0033291798007533

Gizem, Ö., \& Keser, P. B. (2020). Annelerinin ev içi ve ev dış1 rollerine yönelik okul öncesi çocukların görüşlerinin toplumsal cinsiyet açısından incelenmesi. Değerler Eğitimi Dergisi, 18(39), 377-413.

Hazan, C., \& Shaver, P. R. (1987). Romantic love conceptualized as an attachment process. Journal of Personality and Social Psychology, 52(3) 511-524. http://dx.doi.org/10.1037/0022-3514.52.3.511

Hoşoğlu, R. (2017). Üniversite öğrencilerinin romantik ilişkilerinde klskançlıkla başa çıkma biçimlerinin çeşitli değişkenlerle ilişsisi (Yayımlanmamış yüksek lisans tezi). Ankara Üniversitesi, Ankara.

Karasar, N. (2009). Bilimsel Araştırma Yöntemi. Ankara: Nobel Yayın Dağıtım.

Katalan, C. (2014). The relationships between parenting styles, attachment styles and romantic relationship satisfaction, romantic relationship anxiety amoung young Turkish adults (Unpublished doctoral dissertation). Bahçeşehir University, İstanbul.

Kernberg, O. (2008). A ğır kişilik bozukluklarında psikoterapötik stratejiler (A. A. Köşkdere, Çev.). İzmir: Meta Yayıncılık.

Khaleque, A., \& Rohner, R. P. (2002). Reliability of measure assessing the pancultural Association between perceived parental acceptance-rejection and psychological adjustment. Journal of Cross-Cultural Psychology, 33(1), 87-99. http://dx.doi.org/10.1177/0022022102033001006

Klein, M. (2008). Haset ve şükran (O. Koçal Y. \& Erten, Çev.). İstanbul: Metis. 
Kohut, H. (1998). Kendiliğin çözümlenmesi (C. Atbaşoğlu, B. Büyükkal \& C. İşcan, Çev.). İstanbul: Metis.

Korkmaz, K. (2020). Romantik ilişkilerde ilişki doyumu ve yatırımı: Çatışma çözme ve öz-duyarlığın rolü (Yayımlanmamış yüksek lisans tezi). Çukurova Üniversitesi. Adana.

Main, M., Kaplan, N., \& Cassidy, J. (1985). Security in infancy, childhood, and adulthood: A move to the level of representation. Monographs of Thesociety for Research in Child Development, 50(1,2), 66-104.

Metts, S., \& Cupach, W. R. (1990). The influence of relationship beliefs and problemsolving responses on satisfaction in romantic relationships. Human Communication Research, 17(1), 170-185.

Oktay, G. (2016). Algılanan anne-baba tutumu ile bağlanma biçimi arasındaki ilişkinin incelenmesi (Yayımlanmamış yüksek lisans tezi). Üsküdar Üniversitesi, İstanbul.

Olderbak, S., \& Figueredo, A. J. (2009). Predicting romantic relationship satisfaction from life history strategy. Personality and Individual Differences, 46, 604-610.

Öztürk, M. O. (1994). Ruh sağlı̆̆l ve bozuklukları. Ankara: Hekimler Yayın Birliği.

Parlak, S. (2018). Gençlerde partnere yönelik şiddet ve önlenmesi: Bir karma yöntem çalışması (Yayımlanmamış doktora tezi). Marmara Üniversitesi, İstanbul.

Perris, C. (1994). Linking the experience of dysfunctional parental rearing with manifest psychopathology: a theoretical framework. In C. Perris, W.A. Arrindeu, \& M. Eisemann (Ed.), Parenting and Psychopathology. Chichester: John Wiley and Sons.

Rohner, R. P. (1975). They love me, they love me not: A world wide study of the effects of parental acceptance and rejection. New Haven: Human Relations Area Files Press.

Rohner, R. P. (1986). The Warmth dimension: Foundations of Parental AcceptanceRejection Theory. Newbury Park, CA: Sage Publications, Inc.

Rohner, R. P., Khaleque, A., \& Cournoyer, D. E. (2005). Parental acceptance rejection: Theory, methods, cross-cultural evidence, and implications. Ethos, 33(3), 299-334. http://dx.doi.org/10.1525/eth.2005.33.3.299

Roscoe, J. T. (1975). Fundamental Research Statistics for the Behavioral Science. New York: Holt Rinehart and Winston.

Russell-Chapin, L. A., Chapin, T. J., \& Sattler, L. G. (2001). The relationship of conflict resolution styles and certain marital satisfaction factors to marital distress. The Family Journal, 9, 259-264.

Salahur, E. (2010). Üniversite öğrencilerinin geriye dönük olarak çocukluklarında algılamış oldukları ebeveyn kabul veya reddinin yetişkin bağlanma biçimleri ve depresif belirtiler ile ilişkisi (Yayımlanmamış yüksek lisans tezi). Hacettepe Üniversitesi, Ankara.

Santrock, J. W. (2012). Yaşam boyu gelişim: Gelişim psikolojisi. (G. Yüksel, Çev.). Ankara: Nobel Yayıncılık.

Stoeber, J. (2012). Dyadic perfectionism in romantic relationships: Predicting relationship satisfaction and long-term commitment. Personality and Individual Differences, 53, 300-305. 
Sümer, M. (2006). Yetişkinlerin bă̆lanma stillerinin duygusal zekâ, ilişkiye bağlılık, ilişkide algılanan tatmin ve bazı değişkenlere göre incelenmesi (Yayımlanmamış yüksek lisans tezi). Maltepe Üniversitesi, İstanbul.

Sümer, N. (2006). Yetişkin bağlanma ölçeklerinin kategoriler ve boyutlar düzeyinde karşılaştırılması. Türk Psikoloji Dergisi, 21(57), 1-22.

Şahin-Sarkın, B., \& Parlak, S. (2020). Aşka ilişkin tutumların yakın ilişkilerde yaşantıları yordayıcılığının incelenmesi. Education Sciences, 15(3), 63-72.

Towler, A. J., \& Stuhlmacher, A. F. (2013). Attachment styles, relationship satisfaction and well-being in working women. The Journal of Social Psychology, 153(3), 279298.

Uyanık, Ö., Kaya, Ü., İnal-Kızıltepe, G., \& Can-Yaşar, M. (2016). An investigation of the relationship between fathers and their children at preschool level. Journal of Theoretical Educational Science, 9(4), 515-531. Retrieved from https://dergipark.org.tr/tr/pub/akukeg/issue/29364/314189

Wearden, A., Peters, I., Berry, K., Barrowclough, C., \& Liversidge, T. (2008). Adult attachment, parenting experiences, and core beliefs about self and others. Personality and Individual Differences 44, 1246-1257.

Yavuzer, H. (1994). Çocuk psikolojisi. İstanbul: Remzi Kitabevi.

Yıldırım, A., \& Şimşek, H. (2013). Sosyal bilimlerde nitel araştırma yöntemleri. Ankara: Seçkin Kitabevi.

This is an Open Access article distributed under the terms of the Creative CommonsAttributionNonCommercial-ShareAlike 4.0 International (CC BY-NC-SA 4.0). For further information, you can refer to https://creativecommons.org/licenses/by-nc-sa/4.0/ 